Archived version from NCDOCKS Institutional Repository http://libres.uncg.edu/ir/asu/

\title{
Appalachỉan
}

B O O N E, N O R T H C A R O L I N A

\section{Islam Is Everywhere: Pre-Arab Spring Coverage Of Islam In The English Egyptian Press}

\author{
By: Greg Perreault
}

\begin{abstract}
This study investigates how Islam is reported by English-language Egyptian media. Much research has examined the orientalism that occurs in the coverage of Islam in the West, but little has occurred on how Islam is covered in a Muslim-majority context. This study conducted interviews with eight journalists who report on Islam as a part of their beat in Egyptian publications and a news framing analysis was performed on articles relating to Islam in English-language Egyptian news sources Al Ahram Weekly, Daily News Egypt, and Al-Masry Al-Youm in the months before Arab Spring radically altered the shape of the country. By applying orientalism, this study hopes to examine coverage of Islam in an environment where one would expect better portrayal of Islam and to examine the ways in which reporting regarding Islam foreshadowed the changes to come.
\end{abstract}

Greg Perreault (2014). "Islam Is Everywhere": Pre-Arab Spring Coverage of Islam in the English Egyptian Press, Journal of Media and Religion, 13:2, 97-113, DOI: 10.1080/15348423.2014.909207. Publisher version of record available at: https://www.tandfonline.com/doi/full/10.1080/15348423.2014.909207 


\title{
"Islam Is Everywhere": Pre-Arab Spring Coverage of Islam in the English Egyptian Press
}

\author{
Greg Perreault \\ University of Missouri
}

\begin{abstract}
This study investigates how Islam is reported by English-language Egyptian media. Much research has examined the orientalism that occurs in the coverage of Islam in the West, but little has occurred on how Islam is covered in a Muslim-majority context. This study conducted interviews with eight journalists who report on Islam as a part of their beat in Egyptian publications and a news framing analysis was performed on articles relating to Islam in English-language Egyptian news sources Al Ahram Weekly, Daily News Egypt, and Al-Masry Al-Youm in the months before Arab Spring radically altered the shape of the country. By applying orientalism, this study hopes to examine coverage of Islam in an environment where one would expect better portrayal of Islam and to examine the ways in which reporting regarding Islam foreshadowed the changes to come.
\end{abstract}

In contemporary Egyptian society, journalists can be fired, have their printers seized, cause a riot, or find themselves tortured in an Egyptian prison for their coverage. Yet Egyptian journalists have been willing to push the limits of their society, at their own peril, to write and report on subjects they believe are vital for the Egyptian public. But the Egyptian government is equally willing to imprison those journalists and certainly was under the Hosni Mubarack regime (Eltahawy, 2006).

Issues of Islam are sensitive and yet at the heart of Egyptian society. Islam influences fashion, food, lifestyle, and politics. Some attribute this to the power of the Muslim Brotherhood-a conservative political Islam movement in Egypt - that briefly held power after Arab Spring. Similarly, political rhetoric often draws on Islam in order to achieve popular appeal. So it is no surprise that there is no need for an "Islam" beat in Egypt because stories that relate to Islam appear in stories about politics, business and fashion.

One non-Muslim journalist noted that she was essentially a Muslim "simply by virtue of living in Egypt" (Interview 3). Egyptian journalists strive to tell accurate, fair stories about events that matter to the people of their country. Even before Arab Spring, the Egyptian

Correspondence should be addressed to Greg Perreault, 179 Gannett Hall, School of Journalism, University of Missouri, Columbia, MO 65211. E-mail: greg.perreault@gmail.com 
constitution guaranteed freedom of the press. Of course, freedom of the press means little if the police won't stop a riot (Mattingly, 2006). And therein lies the contradictions of Egyptian society.

Past scholarship has well established that Islam is not covered effectively in the West (Said, 1981). Muslims receive overwhelming negative coverage throughout much of the world. Western journalists struggle to cover religion as a whole, but Islam in particular (Marshall, Gilbert, \& Green-Ahmanson, 2008). Yet there has never been a study that tries to understand how Islam is covered in a Muslim-majority context. In this way, it is useful for the journalist as much as the academic to understand the nature of coverage of Islam in Egypt. This study is a first step into that untouched field. It will focus on coverage of Islam in English-language Egyptian press. This research includes a qualitative textual analysis, which looks at coverage of Islam from October 31, 2009 to February 1, 2010-pre-Arab Spring-in Daily News Egypt, Al-Masry Al-Youm, and Al Ahram Weekly. The study will also include interviews from eight key journalists at English-language publications in Egypt. Those interviews provide a window into the world of press coverage of Islam in Egypt.

Islam is not covered in a vacuum. News coverage of Islam in Egyptian English-language focuses on how the faith operates in the lives of everyday Egyptians and how Islam appears in the culture and politics of the country.

\section{THEORETICAL FRAMEWORK}

In the history of press coverage of minority groups, the press is frequently seen as emphasizing conflicts. In coverage of Islam, the press is frequently accused of playing a role in marginalizing the religious faith by othering them-making them appear weird, odd, different, and outside of the mainstream (Said, 1981; Poole, 2000, 2002). Press scholarship has frequently critiqued this state of affairs. Studies suggest that journalism has the ability to reaffirm the outsider status of minority groups (Said, 1979).

Said notes that, if knowledge is power, then Western media have historically been quite powerful as a result of the control over what the world knows about Islam. The Western media have been selective in its choice of images about Islam, portraying Islam as oppressive, with symbols like hijab; outmoded, with hangings, beheadings; and generally backward (Said, 1981). While critical of Western media, Said (1981) claims that there have been reasons for the negative coverage:

The general state of the Islamic world with its decline in productivity and well-being, including such phenomena as censorship, the relative absence of democracy, the dismaying prevalence of dictatorships, and fiercely repressive and authoritarian states ... seems backward and cruel; this includes basically Islamic countries such as Saudi Arabia, Egypt, Iraq, Sudan, and Algeria. (Said, 1981, p. xv)

Said (1981) notes that the Western media have a near hegemonic global power in presenting a sense of what is normative. This normativity simultaneously circumscribes attention to those who do not fit in traditional understandings of what is normal and thus are othered (Said, 1981). This othering happens in particular in the East where Arabs and Muslims in particular 
are presented as needing to be oriented to be more like the West (Said, 1979, 1981; Poole, 2002; Hafez, 2000). Such coverage can result in an identity crisis for Muslims who feel caught between being "Western" and being "Muslim." The Western media portray Islam negatively so thus one can be left feeling either "non-Western" or "non-Muslim" (Farouqui, 2009). Farouqui notes: "The common Muslim is caught between the increasingly strident anti-Muslim propaganda of the West and the equally strident religious fervour of the "jihadi' Muslims" (p. 3).

Yet in the time since Said (1981) wrote, the media paradigm has shifted. The advent of Internet and satellite television has shifted the conversation of orientalism. Al Jazeera, Al Arabiya, and wide proliferation of blogs have challenged the unilateral power that was once held by Western media (Abdulla, 2007). At the same time, this shift in power has also challenged the power of the dictators who once held the Middle East firmly in their grasp (Aouragh \& Alexandar, 2011). Hafez notes that pre-9/11, press coverage of Islam manifested in two paradigms of "globalization" and a "clash of civilizations" (Hafez, 2000). He noted that coverage of Islam is not just problematic because of inaccurate or biased reporting but also because of socio-psychological stereotypes and the commercial interests of media institutions (Hafez, 2000). Post-9/11, press coverage became more troubling-emphasizing themes related to terrorism (Poole, 2006; Richardson, 2006; Manning, 2006; Elgamri, 2008).

\section{LITERATURE REVIEW}

In the Arab world, news historically has been a tool of officials and governors, a way to show their subordinates the route to follow (Ayalon, 1995). And news media are still seen as a sign of modernization and industrialization in the area. Mellor (2005), echoing Said, argued that news is knowledge, knowledge is power and thus, news is power.

Historically, Islam is not the easiest subject for journalists to cover critically in Egypt and throughout the Arab world. In practice, what often causes crackdowns on journalists is public outcry (Eltahawy, 2007; Khazen, 1999; el Mohiebb, 2003; Isherwood, 2008; Alterman, 1998; Mellor, 2008). Alterman (1998) notes that discussion of Islam, especially any discussion that relates to Islamists, is considered taboo. But even if religion is not a taboo, it is certainly a sensitive subject. Hafez (2008) notes that in many ways, the media have served to stay political Islam. But he argues that in Egypt more is expected out of the media than in the West (Hafez, 2008). Under the Mubarack regime, the press was in a remarkably complex environment. Hafez (2008) notes that in asserting control over the media the Egyptian government rewarded positive reporting and chastened negative reporting.

Rugh labels the press system of Egypt as "The Transitional Press." This press system is a "mixed system in which the largest circulation print media are controlled directly by the government but smaller ones are owned by private individuals or parties, and they have some latitude to criticize those in power" (Rugh, 2004, p. 252). Rugh adds that the transitional press is "transitional because it has undergone steady change for more than a decade and because the system itself remains under debate, and appears to be unsettled" (Rugh, p. 121).

This press system is not an accidental byproduct of political realities, but an object of political calculation (Rugh, 2004; Kalb \& Socolovsky, 1999). According to Rugh (2004), the biggest indicator in determining the nature of the relationship between the press and the 
government is the diversity of press publications. In every Arab country, some media will be in complete support of government policy. The essential function of Rugh's "Diverse Press," which Rugh labels as the most free press in the Arab World (in Morocco, Lebanon, Kuwait), is the existence of a genuine opposition to the ruling party, which can function openly. If no public opposition is allowed, it follows that the press will be in one, uniform voice (Rugh). The government does try to restrict the press at times, but it also uses the courts and relies on journalists' self-censorship.

With safety as a concern among journalists, it is not surprising that the most dominant form of censorship in Egypt is self-censorship (Ayalon, 1995; Rugh, 2004; Lynch, 2007; Khazen, 1999). Press censorship is not always legislated and economically motivated; often the harshest censor was the press itself.

Self-censorship is a response and reaction to the strong control measures on the press in Egypt. Some call it the "censorship of the street" (Jacquemond, 2008). One author notes: "You can always come to an accommodation with the official censorship, but how can you get along with people who are scattered from Alexandria to Aswan?" (Jacquemond, p. 61). The greatest government censorship in Egypt occurs on the subject of politics and the coverage of country leaders. Here too, Islam becomes involved. Politicians, in such instances, court opposing approaches, at once attempting to be anti-American, pro-West, secular, and devoutly Muslim (Hammond, 2007).

This difficulty in providing nuanced news coverage of religion manifests globally in poor portrayals of religious minorities. The majority of the research done on the coverage of Islam centers on Western coverage of Islam. Little English language research could be found that investigates how Islam is covered in Muslim-majority countries. However, some recent works have been written on the subject of news coverage of Islam in Europe and Asia.

The poor portrayals of religious minorities are often affirmed through scholarship exploring negative reporting of Islam in particular. This is particularly true when the news reporting of minority traditions are contrasted with majority traditions (Dahinden, Keel, Koch, \& Wyss, 2011). Dahinden et al. note that the negative portrayal of Muslims resulted from overrepresentation relative to their population, one-dimensional portrayals, and an emphasis on conflict-driven stories. This link to conflict appears often through links to crime, violence and terrorism (Broos \& Van den Bluck, 2012).

Yet in some contexts the press also at times presents Muslims favorably, particularly in situations in which religious tension is high. In a study of the representations of Muslims in India, a Hindu majority society, the press was shown to work as a peacemaker (Narayana \& Kapur, 2011).

Poole has performed a number of content analytic studies on British newspapers to see how they cover Islam $(2000,2002,2006)$. Poole found that there are a limited number of frameworks used in representing British Muslims in the press and that the description "Muslim" often implied a foreigner (Poole, 2002).

This literature leads to three essential research questions:

RQ1: With the caveat that all press is culturally and socially situated, what are the similarities in the framing of Islam in Egyptian English press compared with other environments? 
RQ2: What frames are most privileged in the coverage of Islam in the Egyptian English press?

RQ3: To what degree does the coverage of Islam in Egyptian English publications challenge or affirm predominant notions of orientalism?

\section{METHOD}

The research questions for this study are addressed from the interpretivist and humanistic traditions of scholarship, and thus providing generalizability to the findings is not a goal of this study. The goal of this study is to increase the understanding of how the Egyptian English press operated during a key period in recent Egyptian history and of coverage of Islam. The interpretivist tradition has "the capacity to challenge the guiding assumptions of the culture, to raise fundamental questions regarding contemporary social life, to foster reconsideration of that which is 'taken for granted,' and thereby to generate fresh alternatives for social action" (Gergen, 1982, p. 109). This study addresses the research questions through a qualitative news framing textual analysis and interviews with Egyptian journalists at Englishlanguage publications. The textual analysis will provide an understanding of the themes that appear in conjunction with Islam in the journalistic product. The interviews will help reveal the motivations and the socio-cultural context in which journalists operate in covering Islam. Together they provide a picture of how Islam is covered in Egyptian English-language news.

The type of textual analysis employed here is a news framing analysis. This analysis examines the content in terms of the topics that frame the subject matter. In news framing analysis, there is an appreciation that reality is socially constructed. So how Islam is viewed in the United States can have much to do with how the subject is framed. Framing topics with these sorts of accounts can change the direction of discourse on a given issue (Johnson-Cartee, 2005; Entman, 2010; Van Gorp, 2010; Zillman \& Brosius, 2000).

This study employed Poole's $(2002,2006)$ framing scheme for the analysis and many of her search terms in the analysis of the Egyptian press. In Poole (2002), the topics used to frame the discussion of Islam included education, fundamentalism, relationship to Christianity, racism, Muslim community, gender, government, politics, cultural atrocities, Islamophobia, anti-Jewish sentiments, food, and conflict with the West (Poole, 2002). In her post-9/11 study, Poole (2006) limited the topics to: terrorism, politics, war in Iraq, education, discrimination, race relations, media, relationships, crime, and asylum (Poole, 2006). This study will follow a similar procedure of presence and absence coding with the unit of analysis as the article. Poole (2002) solely relied on the search terms of "Muslim" and "Islam" in order to pinpoint relevant articles and these search terms were similarly employed for this study. As a result of weaknesses in the Web site search tools, additional terms were used in order to affirm that a good sample was obtained. The search terms used to gather articles included "Islam," "Muslim," Ramadan," "Fatwa," "Ijtihad," "Coptic," "Shia," "Sunni," and "Hijab." Those terms revealed articles that all concerned Islam in some way, whether implicitly or explicitly.

It is important to note that this study cannot answer how Islam is covered in Arabiclanguage publications. Scholarship has already noted a difference in coverage between Arabic 
and English publications (Eltahawy, 2007). This textual analysis will apply only to Englishlanguage publications. The reasoning for this is practical-this researcher knows little Arabic and discussion with scholars in the field revealed that there are few reliable internet translators for a project this intensive. It also has to be understood that journalists may write differently for an Arabic audience as opposed to English audience, which is primarily elites and foreigners (Johnson-Cartee, 2005, p. 107).

The textual analysis examined a time frame where Islam was a large topic of discussion. The timeframe chosen was October 31, 2009, through February 1, 2010. The timeframe was optimal for that sort of discourse because of the death of a well-known Islamic thinker, shifts of power within the Muslim Brotherhood, and conflict between Coptic Christians- the native Christian population of Egypt - and Sunni Muslims. The three publications were selected on the basis of representing different avenues of news in the Egyptian English community.

Al Ahram Weekly is the English edition of Al Ahram, the largest Arabic circulation print news component in the Middle East with a circulation near 700,000 (Rugh, 2004). The Egyptian government has historically appointed the editor of the news organization (Rugh). The online archives of Al Ahram Weekly stretch back to 1998. The longevity of the news organization, as well as its connections to the government make it a reasonable pick for this study. The Daily News Egypt is the only privately owned daily in Egypt that prints solely in English, and it was selected because of its distance from direct government intervention. It was closed by Egyptian Media Services in 2012 and then later reopened under new management ("Alborsa newspaper," 2012). Al-Masry Al-Youm started in 2003. It was also privately owned but operates both in English and Arabic. Newsroom journalists either write separate stories for the English edition or often translate Arabic language stories into English. The Web site has a heavy emphasis on citizen journalism and blogs. Al-Masry Al-Youm was later renamed the Egypt Independent and was shut down, to much controversy, in 2013 (Attalah, 2013).

The interviews provide an additional source of data to help explain the nature of the coverage of Islam. Interviews were conducted with journalists at influential Egyptian news outlets either in person, via email or Skype, an online video calling system that allows for the transmission of audio and video. Granted, more information was gathered from the in-person and Skype interviews, but some newsrooms had policies that forbid internet audio/video communications. For the most part, journalists provided focused, detailed answers in their email. Organizations where journalists were interviewed include: Daily News Egypt, Al-Masry Al-Youm, Business Today, Egypt Today, The Egyptian Gazette, IslamOnline.Net, and Muslim Media Watch.

The two sets of data-interviews and articles-were collected concurrently. In order to privilege the presentation of the data, the textual analysis results will be discussed next and then used to help extrapolate larger trends from the interviews (Creswell, 2008).

\section{TEXTUAL ANALYSIS}

Eighty-six total articles were surveyed from Daily News Egypt, Al Ahram Weekly, and AlMasry Al-Youm between October 29, 2009, and February 1, 2010. The themes were coded for presence or absence. So if a given theme appears at a frequency of 60, then it appeared in 60 articles (Figures 1 and 2). 


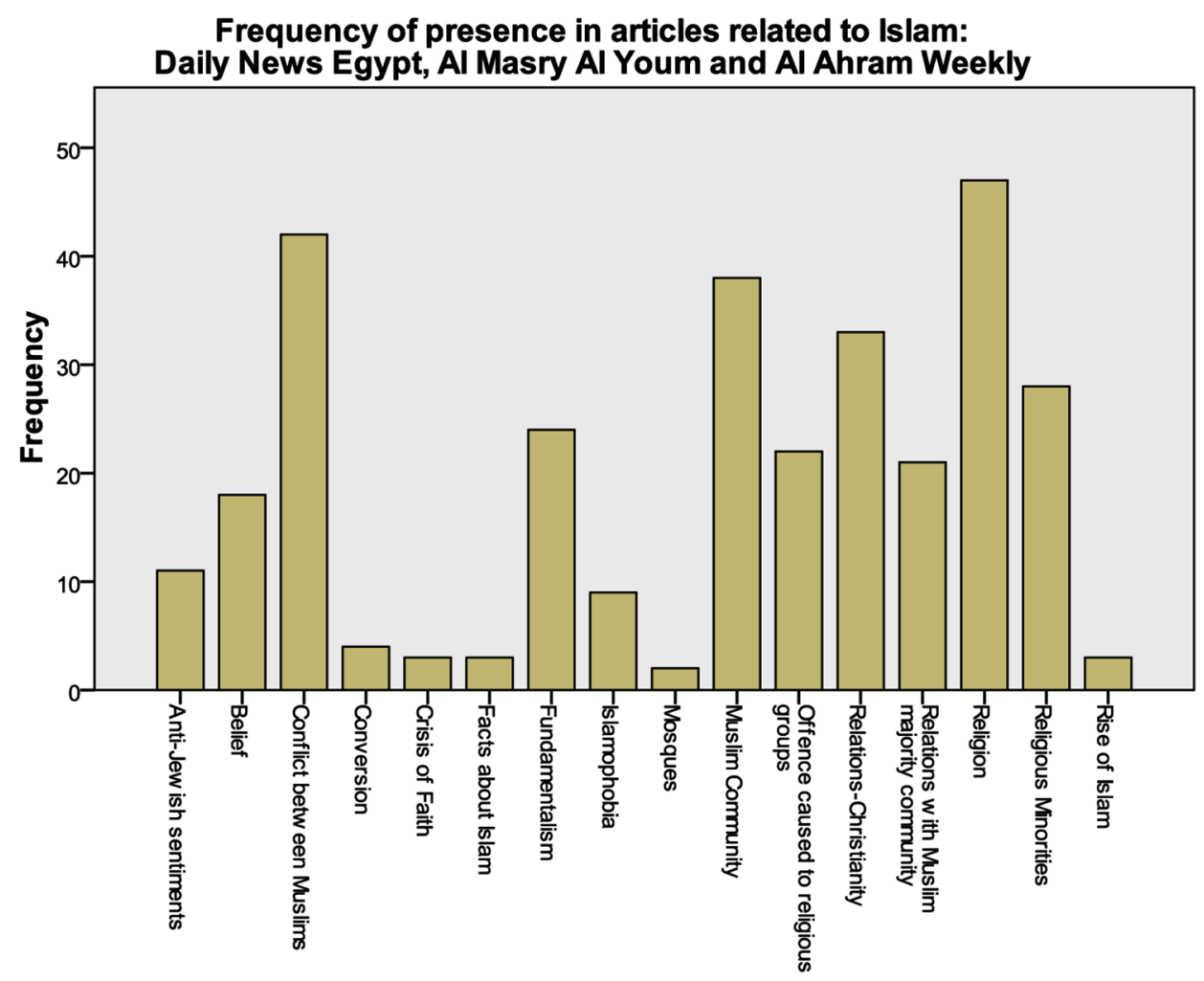

FIGURE 1 The appearance of different elements of religion and religious minorities in coverage of Islam. Frequency denotes the individual number of articles in which the theme appeared. (Color figure available online.)

The themes of "government" and "politics" were highly privileged in this sample. "Government" appeared in 63 of the 86 articles; that is, nearly $75 \%$ of articles that involve Islam also have some connection in the government. Similarly 38 of the 86 articles (44\%) that involve Islam also have a theme of "politics" involved in some way. Interviews indicated that the emphasis on politics might be a result of the Egyptian news industry's preoccupation with the Muslim Brotherhood. In terms of actual discussion of Islam, only 18 articles related to "belief," three articles appeared within the "Crisis of faith," and four articles discuss "conversion." As interviews indicate, the small sample could be a result of caution on the part of journalists concerned about the debate that could be provoked by overt discussions of Islamic theology. Yet those that appeared were highly pertinent to national discussion. For example, Daily News Egypt published an interesting commentary in the wake of the Naga Hammedi shooting about what the Quran actually states about relations to Christians and Jews (El-Ali, 2009).

In terms of discussions about Coptics, "Relations with Christianity" included 33 articles. It should be noted that there was a larger amount of news framing of "relations with Christianity" in Al-Masry Al-Youm than in either Daily News Egypt or Al Ahram Weekly. In Al-Masry Al- 


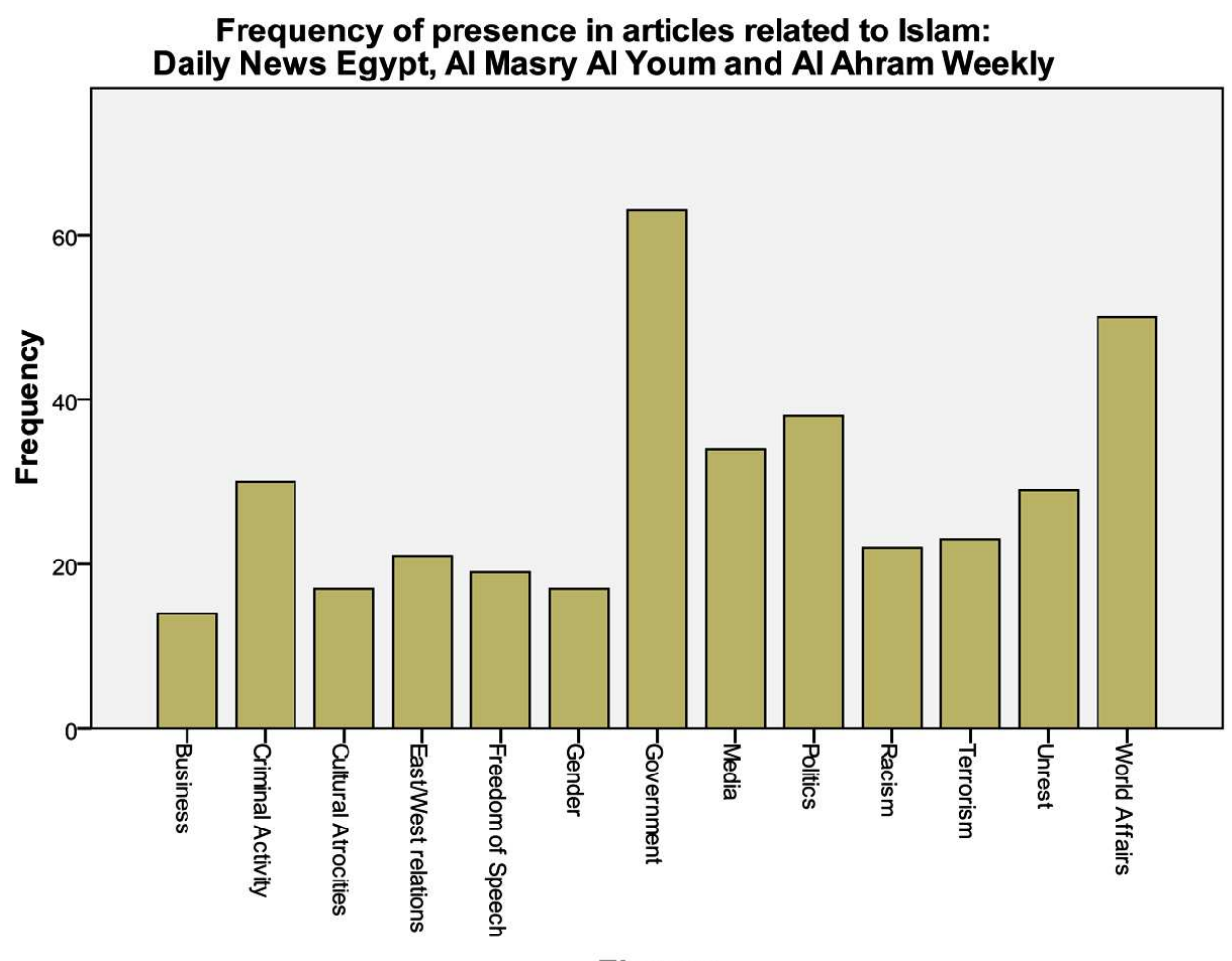

Themes

FIGURE 2 The appearance of government, international politics, crime, and culture in articles concerning Islam. Frequency denotes the individual number of articles in which the theme appeared. (Color figure available online.)

Youm, "The Alienation of Christians" was an interesting article on the subject of Coptic/Muslim discourse in that the Coptic Christians here are "extremists" (el-Hofy, 2009). The theme of "fundamentalism" comes up in some conflicts with Coptics, who are described as radical and extremist in particular in el-Hofy (2009). The article argues that if Coptics want to have better standing in Egypt, they need to make meaningful contributions to Egyptian society.

Interestingly enough this textual analysis located almost no coverage in Al Ahram Weekly of the Nag Hammadi shooting, which was a key moment of violence between Coptics and Muslims. This is significant because the state-run Al Ahram is considered the paper of record in Egypt. This could represent a difference between the Arabic and English language paper, a willful dismissal of the subject as not newsworthy, or a side-effect of the sensitivity of the topic. Only one article was found on the subject in Al Ahram Weekly. This fits in with the larger trend that less coverage affecting the theme "relations with Christianity" is present in Al Ahram Weekly than in Daily News Egypt—if only by a little—or Al-Masry Al-Youm.

In one of the expected results, there was a heavy emphasis on "world affairs" in the sample50 articles. This may be indicative of the audience, primarily elite Egyptians and foreigners, 
or a manifestation of Lynch's (2006) theory that it is easier to cover a neighboring country than one's own (Lynch, 2006). There were also 21 articles discussing "East/West relations" that usually centered on relations with Britain or the United States. There were 12 articles that appeared as "Anti-Western," but most of them (10) were from Al Ahram Weekly. No such article appeared in Daily News Egypt and only two appeared in Al-Masry Al-Youm.

Another interesting trend was the number of articles relating to violence. For the term "terrorism," events such as the Nag Hammadi shooting were removed. They were, of course, terrifying events but the shooting seemed like it would have skewed the numbers. "Terrorism" instead reflects references to terrorist organizations who perform terrorist activities - such as Hamas, Al Qaeda, Hizbollah. Terrorism appeared in 23 articles, and here the vast majority of them appeared (11 articles) in the state-run Al Ahram Weekly. That was more than expected, judging from the criticisms of terrorism coverage in the West. This could speak to a shared concern about terrorists who consider themselves "Islamic" or could be representative of the audience for whom they are writing. A higher number of articles included the theme of "criminal activity" at 30 articles and "unrest" at 29 articles. Many of the articles about "unrest" referred to riots that occurred in response to the trial of a Coptic man who raped a Muslim woman and the Nag Hammadi shooting that followed.

Finally, it is worth noting that nearly $50 \%$ of the articles, 42 of 86 , allude in some way to "conflicts between Muslims." This included everything from conflict over theology to political disagreements. But in all cases it is made clear that the actors in question are Muslim. This indicates a key difference from predominant findings on reporting on Islam: Islam is not seen monolithically in Egypt, but is as different as each person's interpretation of the religion. Many of the trends that appeared in the textual analysis reappeared in the analysis of interviews.

\section{INTERVIEWS/DISCUSSION}

During the course of the study, eight Egyptian journalists were interviewed. All of these news organizations are either English and Arabic or English-only. Due to the sensitivity of the study, all personalities at these organizations spoke on the condition of anonymity. Several themes arose in response to this during the interviews, and many of the findings are reinforced by the textual analysis findings. For each of them the findings on the subject will be summarized, followed by a selected quote in that regard. The quotes included are not edited for grammar or cohesion to be true to the information. Bracketed information is only used to provide context for the quoted material.

\section{Islam Is Covered Mainly in Relation to Culture and Politics}

Journalists stressed that there is no need for an "Islam beat" in Egypt because Islam is everywhere. One journalist said that Egyptian journalists do not see their work as "religion" stories because religion is so intertwined with culture and politics (Anonymous, personal communication, March 30, 2010). Journalists noted that almost every story in Egypt can relate in some way to Islam - anything related to politics and culture will in some way tie into Islam (Anonymous, personal communication, March 17, 2010; Anonymous, personal communication, March 28, 2010). One journalist, a non-Muslim, noted that it was interesting that often Islam 
is used as a tool in politics. The rhetoric of Islam is very popular with the people and by using it a politician can gain traction even if there is little genuine behind it. Journalists noted that Islam especially appears in stories about the Muslim Brotherhood and in stories about "sectarian strife"-which is typically indicative of conflict between Coptic Christians and Sunni Muslims.

I don't cover Islamic issues proper. But by nature of living in a place like Egypt where Islam is extremely omnipresent in many facets of life, it comes up in many stories. Whether directly or indirectly ... Islam is all over the place. You could be doing a woman's story and end up calling a religious authority to comment. Which was the case with me ... when I wrote about women protesting that they cannot become judges at the state council so one of the things I did was called up a shah and asked, 'Is there anything in Islam that explicitly says women cannot be judges?' I took his voice on that. (Anonymous, personal communication, March 17, 2010)

One journalist noted that one of the key ways that Islam becomes a part of the story is in the sourcing. If the source is outspoken about his faith, it would be journalistically inaccurate to not include it as part of the story (Anonymous, personal communication, March 11, 2010).

\section{Islam Is Covered With Great Sensitivity on the Part of the Journalist}

Perhaps a reason journalists continue to cover the political/cultural aspects of Islam is a result of the sensitive nature of covering the actual theology. One journalist noted that in a typical local newspaper in Egypt, there is page after page of political and cultural content that relates to Islam in some way. But the actual "religion" page is often just a single page. Some journalists said they felt intimidated by writing stories on Islam, others said they avoided stories on Islam, and still others recounted stories of tense occasions that followed when they did cover the story. Almost every journalist said they were comfortable covering stories that related to Islam-which may also indicate their adeptness at covering a subject that is a part of their culture and politics—but many also could quickly summon stories that were especially difficult (Anonymous, personal communication, March 21, 2010; Anonymous, personal communication, March 29, 2010; Anonymous, personal communication, March 30, 2010).

Thankfully, I try to run away from any stories concerning Islam. I feel that people won't be as objective when they see me or they won't believe that I'm an objective person because I wear the veil. As a result, I usually try to go for the more political stories or features, something that's a bit more light-hearted ... [On more controversial stories, potential sources] will usually refuse to get quoted or be included in your article. They don't want to be looked down on or considered odd. As I had mentioned before, Islam is a very sensitive issue in Egypt. You have opposite ends of the spectrum and very few people in the gray area in the middle. (Anonymous, personal communication, March 21, 2010)

All of the journalists stressed the importance of being "objective" and quoting sources with whom they disagree. That stance caused some of those journalists a considerable amount of hate mail. One journalist noted that if one quotes a source, and allows them a platform for discourse, this indicates agreement with the source. For example, one journalist discussed a story she wrote on Ba'hais in which she quoted Ba'hais at length. She said she got angry mail that accused her of being a heretic (Anonymous, personal communication, March 30, 2010). 
With that in mind, journalists argued that if they refused to quote minority religious perspectives their work could be more positively received. Quoting minority religious perspectives can be a cause for controversy among readers.

\section{English-Language Journalists Feel They Have Some Leeway in Reporting on Islam}

This study can make no claims as to how Arabic-language publications compare to Englishlanguage publications in coverage of Islam, but many journalists indicated they saw a distinct difference. When asked about the attitude toward covering Islam at their publication, several responded by claiming that they had "more" freedom than if they were at an Arabic-language publication. The differentiations perhaps say less about Arabic-language publications and more about how English-language journalists view their occupation and their coverage. Journalists spoke about their desire to cover Islam "fairly" and "objectively."

We cover stories concerning human rights in all its forms, whether in terms of religion, freedom of expression, etc. I can't think of anything to be done differently simply because I have never felt I was pressured into covering a story in a certain way. In almost two years working at [this publication], not once did an editor come up to me and told me not to cover this or took out parts of a story I've sent. I consider this a 'blessing' given the fact that I'm a journalist in Egypt.... The fact that the majority of Egyptians don't speak English makes the authorities let a lot of things we cover pass. But I can imagine that they are more attentive to Arab media and the content published or broadcasted there. On the other hand, being an English newspaper, even though we can reach only a small portion of the society, we reach the decision makers, those who can make a difference after reading an article in our newspaper, which is a great advantage we have. (Anonymous, personal communication, March 14, 2010)

Journalists overwhelmingly felt that they had a degree of freedom because the majority of the Egyptian population doesn't read English. So by reporting in English, they feel they have the freedom to cite sources that would more often cause a ruckus.

\section{Journalists Are Keenly Aware of Concerns, in Both Egypt and Abroad, of Islamic Fundamentalists and Terrorists Operating in the Name of Islam}

Journalists noted their dissatisfaction with the international press which, at times, stereotypes them as extremists or terrorists. Yet nearly a quarter of the articles surveyed still allude to terrorism in some way when discussing Islam (Table 1). Journalists were resistant about the typecast role that Western media often provides; yet many also seemed to want to answer for things done in the name of Islam. Interestingly, this topic came up in every interview despite the fact that there was no question posed about terrorism and Islam. Their responses could perhaps be a result of overwhelming Western study of Islam and terrorism. Perhaps thinking that was this researcher's primary objective, many respondents chose to allude to it.

I think that the topic of Islam has a lot of aspects to it, just like that of any other religion. There's the good and the bad.... Islam is a hot topic around the world, especially after $9 / 11$ and a lot of people are still trying to grasp it and get their hands around it and to understand what it means and what it's all about and these are all things that we-as journalists on this side of the world—-should take advantage of. (Anonymous, personal communication, March 21, 2010) 
TABLE 1

Data From Textual Analysis of Al Masry Al Youm, Al Ahram Weekly, and Daily News Egypt Coverage of Islam October 31, 2009 Through February 1, 2010

\begin{tabular}{|c|c|c|c|c|c|c|c|c|}
\hline Publication & $\begin{array}{c}\text { Adjustment } \\
\text { to Culture } \\
\text { Sum }\end{array}$ & $\begin{array}{l}\text { Anti-Jewish } \\
\text { Sentiments } \\
\text { Sum }\end{array}$ & $\begin{array}{c}\text { Anti- } \\
\text { Western } \\
\text { Sum }\end{array}$ & $\begin{array}{c}\text { Belief } \\
\text { Sum }\end{array}$ & $\begin{array}{l}\text { Business } \\
\text { Sum }\end{array}$ & $\begin{array}{l}\text { Conflict } \\
\text { between } \\
\text { Muslims } \\
\text { Sum }\end{array}$ & $\begin{array}{l}\text { Conversion } \\
\text { Sum }\end{array}$ & $\begin{array}{c}\text { Criminal } \\
\text { Activity } \\
\text { Sum }\end{array}$ \\
\hline Al Masry Al Youm & 2 & 3 & 2 & 6 & 7 & 15 & 0 & 12 \\
\hline Al Ahram Weekly & 3 & 7 & 10 & 6 & 4 & 14 & 3 & 7 \\
\hline Daily News Egypt & 1 & 1 & 0 & 6 & 3 & 13 & 1 & 11 \\
\hline Grand Total & 6 & 11 & 12 & 18 & 14 & 42 & 4 & 30 \\
\hline Publication & $\begin{array}{c}\text { Crisis } \\
\text { of Faith } \\
\text { Sum }\end{array}$ & $\begin{array}{c}\text { Cultural } \\
\text { Atrocities } \\
\text { Sum }\end{array}$ & $\begin{array}{l}\text { Cultural/ } \\
\text { Legal } \\
\text { Differences } \\
\text { Sum }\end{array}$ & $\begin{array}{c}\text { Deprivation } \\
\text { Sum }\end{array}$ & $\begin{array}{l}\text { East/West } \\
\text { Relations } \\
\quad \text { Sum }\end{array}$ & $\begin{array}{l}\text { Education } \\
\quad \text { Sum }\end{array}$ & $\begin{array}{l}\text { Facts } \\
\text { about } \\
\text { Islam } \\
\text { Sum }\end{array}$ & $\begin{array}{l}\text { Food } \\
\text { Sum }\end{array}$ \\
\hline Al Masry Al Youm & 1 & 8 & 3 & 9 & 5 & 4 & 0 & 0 \\
\hline Al Ahram Weekly & 2 & 4 & 4 & 0 & 12 & 4 & 1 & 0 \\
\hline Daily News Egypt & 0 & 5 & 4 & 0 & 4 & 3 & 2 & 0 \\
\hline Grand Total & 3 & 17 & 11 & 0 & 21 & 11 & 3 & 0 \\
\hline
\end{tabular}

\section{Many Concerns About the Coverage of Islam Are Rooted in Perceived Societal Problems}

One journalist noted that if Egyptian society cared more about religious minorities, they would probably receive more coverage (Anonymous, personal communication, March 30, 2010). One journalist wanted to do a story on the Shi'a population in Egypt, but she had never met a Shi'a. They do represent a small minority in Egyptian society, yet she struggled with whether she had never met a Shi'a or whether she had never met a Shi'a willing to self-identify as Shi'a (Anonymous, personal communication, March 11, 2010). Another journalist in a similar situation was able to find a story about an imprisoned Shi'a but the problem came when she tried to find the story's parajournalists - the sources, the public relations officials, and the spokespeople (Schudson, 2003). The problem was that she had a difficult time finding an organization that spoke for the Shi'a people.

The problem we face in Egypt is that we don't care about minorities. (Anonymous, personal communication, March 30, 2010)

Usually the stories regarding religious minorities tend to be about discrimination of some sort. Sunni Islam being the majority faith in Egypt, there won't be any stories of that nature unless it involves sectarian violence, where there can be attacks from both sides. (Anonymous, personal communication, March 29, 2010)

Journalists noted that Egyptian society can be discriminatory toward religious minorities; that is, Coptic Christians face many legal obstacles to build churches, and anti-Semitic materials are sold openly. Although journalists can be exceptionally sensitive to their concerns as a human rights issue, a journalists' concern means little without the readers' concern (Anonymous, personal communication, March 11, 2010; Anonymous, personal communication, March 28, 
2010; Anonymous, personal communication, March 30, 2010). The textual analysis indicated that "religious minorities" do receive quite a bit of coverage, but the interviews seemed to indicate that this was by virtue of the time period chosen and representative of the audience.

\section{The Disaggregated Data Show Substantial Differences Between Coverage in the State-Run Al Ahram Weekly and the Privately-Owned Al-Masry Al Youm and Daily News Egypt}

Al Ahram Weekly's coverage in this study is far different than that of the two independent news organizations in this study (see Table 2). It has the heaviest coverage in five key themes. In Al Ahram Weekly, the "Anti-Western" theme appeared in 10 articles as opposed to two in Al-Masry Al-Youm and none in Daily News Egypt. "Criminal Activity" appeared substantially less in Al Ahram Weekly (seven articles) as opposed to Al-Masry Al-Youm (12 articles) and Daily News Egypt (11 articles). The theme of "East/West Relations" appeared in 12 articles in Al Ahram Weekly as opposed to smaller numbers in Al-Masry Al-Youm (5 articles) and Daily News Egypt (4 articles). The theme of "Government" appeared slightly less in Al Ahram Weekly (18 articles) than in Al-Masry Al-Youm (21 articles) and Daily News Egypt (24 articles). Finally, the theme of "Terrorism" appeared substantially more in Al Ahram Weekly (11 articles) than in Al-Masry Al-Youm (5 articles) and Daily News Egypt (7 articles).

There are a couple of possible reasons for the difference in coverage. First, and as previously noted, Al Ahram Weekly is a state-run institution as opposed to a privately owned institution. If the idea behind English-language press is to reach elites and foreigners, then Al Ahram Weekly may be seen largely as an outward-facing media-portraying Egypt the way the state wants it to be portrayed. But also, Al Ahram Weekly is the only one of three English-language institutions that is printed-the online component is secondary. But for Al-Masry Al-Youm and Daily News Egypt, the online component is primary. This could also speak to a difference of medium and the audience expectancy from that medium.

\section{CONCLUSION}

This study found that some facets of Islam - theology, minority perspectives, and the relationship to the Hosni Mubarack regime-were difficult for journalists to address. Most facets, such as cultural issues and the like, are completely natural and unavoidable. This confounding of religion and government is particularly difficult for journalists to address. Journalists concern about this topic is reflective of the societal concern regarding the topic, which led to the downfall of Mubarack, the rise of Muslim Brotherhood leader Mohammed Morsi, and finally, the downfall of Morsi as well. In a regime as powerful as Mubarack's, journalists understandably saw both a danger and a responsibility when confronted with stories about government. The results-obtained prior to Arab Spring - say much regarding the arrival of Arab Spring and its dissolution into Arab Winter. Journalists both in interviews and in their articles expressed a level of cultural anxiety and fixation regarding the religious minorities in their country, in particular, the Muslim Brotherhood. That hegemonic discourse relies on the strong imposition of a status quo-a status quo that was enforced, at times violently, under Mubarack 


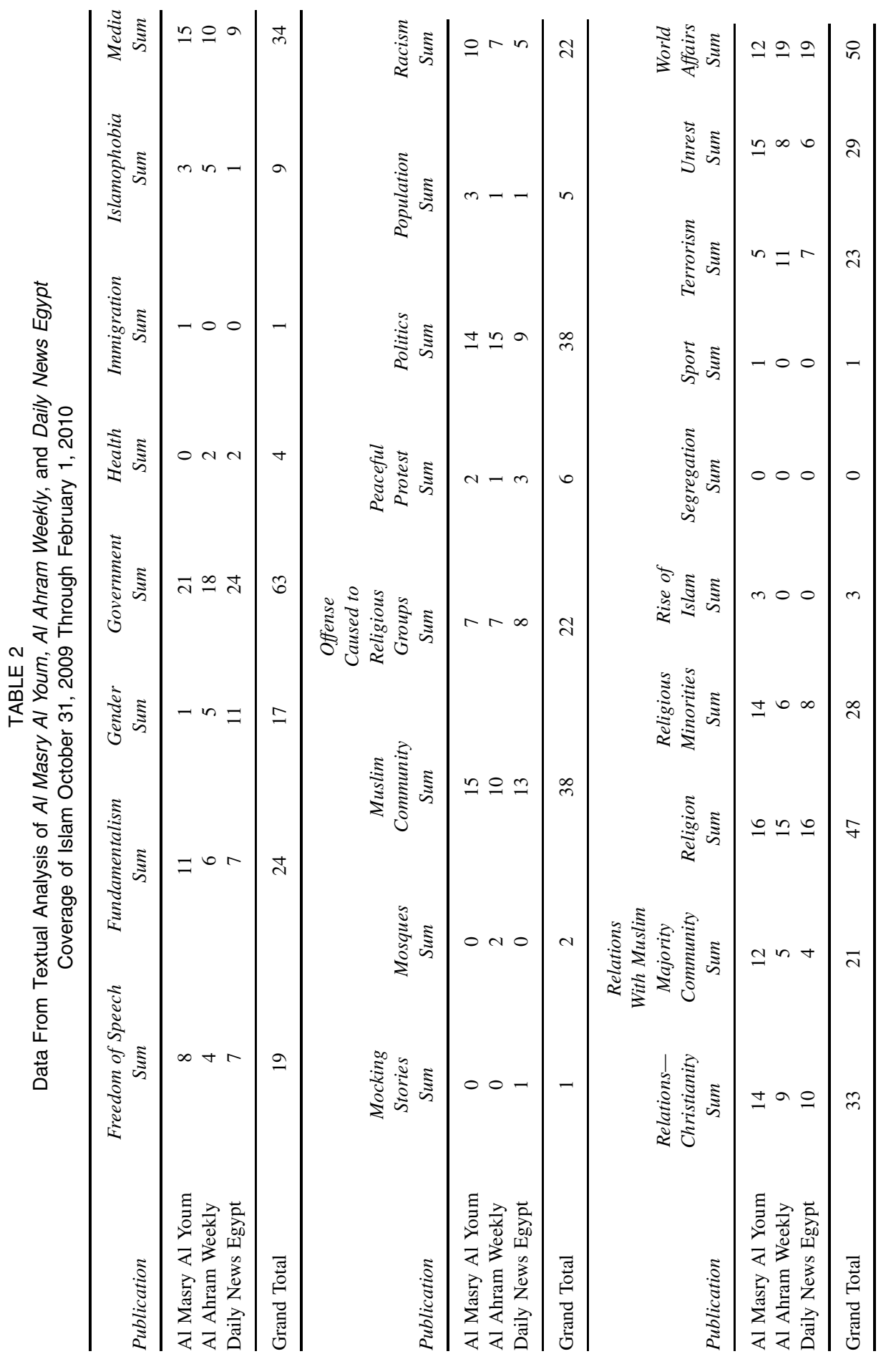


(Gramsci, 2012). With the dissolution of that hegemony, the country has been in flux both to the benefit and the danger of religious minorities (Kymlicka \& Pfostl, 2014).

There are two ways to consider the results of this study in relation to orientalism. First, it is possible to consider that this is an orientalism-light media environment and this would be supported by Said $(1979,1981)$ in that his research focused on primarily Western approaches to coverage of the orient. Understandably, the Egyptian English press didn't other Muslims in the way that is too common in the West. That said, there were many commonalities between Western media coverage of Islam and Egyptian English coverage of Islam, in particular in the emphasis on conflict, terrorism, and the confounding of religion and politics (Hafez, 2000; Poole, 2002, 2006).

Second, if orientalism is considered in abstraction to apply to religious majorities and minorities, then one could see this study as affirming orientalism. With Sunni Islam as the religious majority, the groups that then become othered by the press become the Muslim Brotherhood, Coptic Christians, and Shi'a Muslims. In a sense, this presents a sort of double orientalism in that a minority perspective in an Eastern culture is othered. Here all that has changed is the object of orientalism, the operator of it and the nature of the hegemonic discourse that informs this operation (Said, 1979).

Future research should consider the differences and similarities in coverage of religious minorities in the East and the West. If the results of this study are compared with predominant research in Western media, this could be a potentially fruitful line of inquiry. In addition, Egypt has gone through substantial societal change as a result of Arab Spring and it would be worth exploring how coverage of Islam has changed in the years since Arab Spring.

In processing the results of this study, it is key to note that this researcher is an American. It is impossible to know to what degree responses were shaped toward what journalists thought this researcher wanted to hear, or used the opportunity of this study to shape coverage of Islam in Egypt the way they wanted to shape it.

This study has performed a textual analysis of three English-language Egyptian publications, including Daily News Egypt, Al-Masry Al-Youm, and Al Ahram Weekly. And this researcher has also performed interviews with eight key journalists and editors at differing English-language news organizations. This study found that Islam is covered mainly in relation to culture and politics, Islam is covered with great sensitivity on the part of the journalist, Englishlanguage journalists feel they have some leeway in reporting on Islam, concerns about Islamic fundamentalists and terrorists claiming to be Islamic are still key in English-language Egyptian publications, many concerns about coverage of Islam are rooted in perceived societal problems, and finally that there are substantial differences between coverage in the state-run press and the independent press.

\section{REFERENCES}

Abdulla, R. A. (2007). The Internet in the Arab world: Egypt and beyond (Vol. 43). Bern, Switzerland: Peter Lang. Alborsa Newspaper invests in re-publishing Daily News Egypt. (2012). Daily News Egypt. Retrieved from http://www. dailynewsegypt.com/2012/05/18/alborsa-newspaper-invests-in-re-publishing-daily-news-egypt

Alterman, J. (1998). New media, new politics: From satellite television to Internet in the Arab world. Washington, DC: Washington Institute for Near East Policy. 
Aouragh, M., \& Alexander, A. (2011). The Arab spring The Egyptian experience: Sense and nonsense of the Internet revolution. International Journal of Communication, 5, 15.

Attalah, L. (2013). Egypt Independent, 2009-2013.

Ayalon, A. (1995). The press in the Arab Middle East. Oxford, England: Oxford University Press.

Broos, D., \& Van den Bulck, H. (2012). One religion, many identities? The reception of Islam related news items by Muslim women with Turkish, Moroccan, and Flemish roots in Flanders. Middle East Journal of Culture and Communication, 5, 116-134.

Creswell, J. W. (2008). Research design: Qualitative, quantitative, and mixed methods approaches: Thousand Oaks, CA: Sage.

Dahinden, U., Keel, G., Koch, C., \& Wyss, V. (2011). Representation of Islam and Christianity in the Swiss media. Journal of Empirical Theology, 24, 197-208.

el-Hofy, N. (2009, December 8). Swiss president warned of conspiracy to deport Muslims. Al-Masry Al-Youm. Retrieved from http://www.almasryalyoum.com/en/print/5076

el Mohiebb, A. (2003). Islam in the Middle East: A contemporary snapshot of Egyptian society. Transformation, 20(4).

Elgamri, E. (2008). Islam in the British broadsheets: The impact of Orientalism on representations of Islam in the British press. Reading, England: Ithaca Press.

Eltahawy, M. (2006). This house believes that Arab media needs no lessons in journalism from the West. Doha Debates. Qatar: Qatar Foundation.

Eltahawy, M. (2007, Spring). Meditations on Egypt and election violence. Arab Media \& Society. Retrieved from http://www.arabmediasociety.com/index.php?article $=54 \& \mathrm{p}=0$

Entman, R. (2010). Framing media power. In P. D’Angelo \& J. Kuypers (Eds.), Doing news framing analysis. New York, NY: Routledge.

Farouqui, A. (2009). Muslims and media images: News versus views. Oxford, England: Oxford University Press.

Gergen, K. (1982). Toward transformation in social knowledge. New York, NY: Springer-Verlag.

Gramsci, A. (2012). Selections from the prison notebooks of Antonio Gramsci (Q. Hoare \& G. N. Smith, Trans.). New York, NY: International Publishers.

Hafez, K. (2000). Islam and the West in mass media. Cresskill, England: Hampton Press.

Hafez, K. (2008). Introduction and the unknown desire for 'objectivity': Journalism Ethics in Arab (and Western) journalism. Arab Media: Power and Weakness (pp. 1-14, 147-164). New York, NY: Continuum International Publishing.

Hammond, A. (2007). Popular culture in the Arab world: Arts, politics, and the media. Cairo, Egypt: The American University in Cairo Press.

Isherwood, T. (2008, Fall). A new direction or more of the same? Political blogging in Egypt. Arab Media \& Society. Retrieved from http://www.arabmediasociety.com/?article $=693$

Jacquemond, R. (2008). Conscience of the nation: Writers, state and society in modern Egypt. Cairo, Egypt: The American University in Cairo Press.

Johnson-Cartee, K. (2005). News narratives and news framing: Constructing political reality. Lanham, MD: Rowman and Littlefield.

Kalb, M., \& Socolovsky, J. (1999). The emboldened Arab press. The Harvard International Journal of Press Politics, 4(3).

Khazen, J. (1999). Censorship and state control of the press in the Arab world. The Harvard International Journal of Press Politics, 4(3).

Kymlicka, W., \& Pfostl, E. (2014). Multiculturalism and minority rights in the Arab world. New York, NY: Oxford University Press.

Lynch, M. (2006, July 31). This House believes that Arab media needs no lessons in journalism from the West [Interview by T. Sebastian]. Doha Debates. Retrieved from http://www.thedohadebates.com/debates/item/?d=21\&mode= transcript

Lynch, M. (2007, Spring). Blogging the new Arab public. Arab Media \& Society. Retrieved from http://www.arabmediasociety. com/?article $=10$

Manning, P. (2006). Australians imagining Islam. In E. Poole \& J. Richardson (Eds.), Muslims and the news media. New York, NY: I.B. Tauris.

Marshall, P., Gilbert, L., \& Green-Ahmanson, R. (2008). Blind spot: When journalists don't get religion. New York, NY: Oxford University Press. 
Mattingly, T. (2006, July 12). Fighting blasphemy laws is blasphemy. Terry Mattingly: On religion. Retrieved from http://www.tmatt.net/2006/07/12/fighting-blasphemy-laws-is-blasphemy/

McNair, B. (1998). The sociology of journalism. New York, NY: Oxford University Press.

Mellor, N. (2005). The making of Arab news. Lanham, MD: Rowman and Littlefield.

Mellor, N. (2008). Modern Arab journalism. Edinburgh, Scotland: Edinburgh University Press.

Narayana, U., \& Kapur, P. (2011). Indian media framing of the image of Muslims: An analysis of news coverage of Muslims in English newspapers of India. Media Asia, 38(3), 153-162.

Poole, E. (2000). Newspaper coverage of Islam in the British press. In K. Hafez (Ed.), Islam and the West in mass media. Cresskill, England: Hampton Press.

Poole, E. (2002). Reporting Islam: Media representations of British Muslims. New York, NY: I.B. Tauris.

Poole, E. (2006). The effects of September 11 and the war on terror. In E. Poole \& J. Richardson (Eds.), Muslims and the news media. New York, NY: I.B. Tauris.

Richardson, J. (2006). Who gets to speak? A study of sources in the broadsheet press. In E. Poole \& J. Richardson (Eds.), Muslims and the news media. New York, NY: I.B. Tauris.

Rugh, W. (2004). Arab mass media: Newspapers, radio and television in Arab politics. Westport, CT: Praeger.

Said, E. (1979). Orientalism. New York, NY: Vintage Books.

Said, E. (1981). Covering Islam. New York, NY: Vintage Books.

Schudson, M. (2003). The sociology of news. New York, NY: W.W. Norton \& Company.

Van Gorp, B. (2010). Strategies to take subjectivity out of framing analysis. In P. D’Angelo \& J. Kuypers (Eds.), Doing news framing analysis. New York, NY: Routledge.

Zillmann, D., \& Brosius, H.-B. (2000). Exemplification of communication: The influence of case reports on the perception of issues. Mahwah, NJ: Lawrence Erlbaum. 